\title{
The Service Academies: Eminent Victorians
}

\author{
Bruce Fleming
}

Published online: 29 November 2011

(C) Springer Science+Business Media, LLC 2011

The most visible buildings and those that set the architectural tone of the U.S. Naval Academy, where I've taught English for almost a quarter century, are in a florid American Beaux-Arts late Victorian style. They date from 1904, the first administration of President Teddy Roosevelt with the Dear Old Queen herself only a few years gone, and when what many commentators call the "long Edwardian summer" had barely reached its zenith. Their architect was Ernest Flagg, designer of Washington, D.C.'s first art museum, the copper-roofed Corcoran, and of New York's garlanded Scribner Building on Fifth Avenue. But it's not just the buildings of the Naval Academy that are Victorian; it's the warp and woof of the institution itself, and by extension the other American service academies, whenever they were founded (West Point/Army in 1802, Annapolis/ Navy in 1845, King's Point/Coast Guard in 1876, and Colorado Springs/Air Force not until 1959, when the Army Air Corps separated off and became independent).

The US military academies keep up the simulacrum of living, breathing Victoriana in a way that even the European military academies have largely abandoned. Sandhurst, the British West Point, has given up on the monastic undergraduate program which is the core of the American service academies and instead runs a cluster of various programs of various periods for various ages, as a sort of smorgasbord of military skills curricula; at the German military academy, students wear no uniforms, and the Australian academy has contracted its academics out to the University of New South Wales. Even the Canadian academy at Kingston, Ontario, the Royal Military College,

B. Fleming $(\bowtie)$

Department of English 12B, US Naval Academy,

Annapolis, MD 20402, USA

e-mail: fleming@usna.edu which still runs its own undergraduate education like its southern cousins and remains most like the American, allows students to marry and live off campus and be in their $30 \mathrm{~s}$, none of which are possible at the American academies - which house all students together, forbid marriage or indeed sex of any sort on their grounds, and take students only up to their 24th birthday.

In "The Mark on the Wall," Virginia Woolf dismissed as dead by 1917 the world of the Victorians where "[t]here was a rule for everything. The rule for tablecloths at that particular period was that they should be made of tapestry with little yellow compartments marked upon them ... Tablecloths of a different kind were not real tablecloths. ..." (45) (Virginia Woolf, "The Mark on the Wall," in Monday or Tuesday, DigiReads, 2009, 43-49).

At Annapolis and its American sister academies, this world, almost a century after Woolf wrote, is alive and well: there is a rule for everything. Only one version of things is allowed, and most things may not exist in any version at all. Tablecloths don't exist at all: there are none in King Hall, where more than 4,000 midshipmen simultaneously eat each of their three meals a day. Uniforms are, well, uniform: only this garment may be worn at this time; you have to check a centralized data source to find out what the Uniform of the Day is, and that's what you wear. And you wear it in a certain way: medals in a certain order, brim of hat two fingers' width from the top of the nose. Winter uniforms switch to summer at a point determined by the calendar, short sleeves in sometimes blustery April mocking the actual cold, and winter long sleeves introduced in the midst of a balmy fall's Indian summer. Earrings for women will be a regulation size gold ball: nothing else is allowed. Personal photographs in rooms are permissible only an regulation cork board. Books will be arranged on shelves from tallest to shortest. Study hours are from X to 
Y. Workout times are Z. Hair will be a certain length (short for men, worn in a bun for women) and tattoos, discouraged for the last several years, may not be visible outside of gym clothes.

In the same essay (sometimes classified as a short story, and indeed it could be called either), Woolf makes ironic fun of the Table of Precedency from Whitaker's Almanac, which listed the invariable order in which, senior to junior, people left the room after dinner, or entered it before: all of society had its hierarchy, and Whitaker knew how to order a Bishop and an Earl and a General, making one vast military of all of society. Moreover, this hierarchy was real, and of course could not be challenged. "[F]or who will ever be able to lift a finger against Whitaker's Table of Precedency? The Archbishop of Canterbury is followed by the Lord High Chancellor; the Lord High Chancellor is followed by the Archbishop of York. Everybody follows somebody, such is the philosophy of Whitaker; and the great thing is to know who follows whom" (47).

All this was a creation of men; Woolf's bugbear was "the masculine point of view which governs our lives, which sets the standard, which establishes Whitaker's Table of Precedency, which has become, I suppose, since the war half a phantom to many men and women, which soon, one may hope, will be laughed into the dustbin where the phantoms go" (47).

And her wish has largely come true. In most of Western society, the rules have been laughed into the dustbin of history governing which rank precedes the other out of the room-save for some nod to the precedence of elder over younger, or the rights of hosts and hostesses on their own domain that remain as faint echoes of this notion.

Yet the full-blown equivalent of Whitaker's Table of Precedency is the backbone of the service academiesmuch more so even than in the military itself for which the academies purport to be preparation. Whereas mission effectiveness will frequently trump protocol in the real military where the rules themselves are keyed to functionality, the service academies are more about the show of things than getting things done. The midshipmen, as its students are called in echo of young trainees who actually served amidships during the 18th and 19th centuries, are trained to refer to the buildings in nautical terms. They go down "passageways," visit the "head," and go one "deck" up in stabile, land-becalmed buildings. Yet the Naval Academy is not a ship, and it's not underway. So that leaves an awful lot of time to be filled with play-acting as if it were.

Thus the saluting and the sirring that can be put on hold when there is real work to be done, or that get in the way in combat, can, and do, assume center stage at the academies. The means of the military - protocol to ensure disciplinebecome the end, and are more finely calibrated. Midship- men check their watches before saying "Good morning [Good afternoon] Sir/Ma'am" and if they see an officer ten times an hour must salute him or her each time. Distinctions between the ranks of MIDN 4/C[lass] and 3/C, divided by a single year, are rigidly observed (the $4 / C$, newbies, must address anyone above them as "sir" or "ma'am"), and the gods are the $1 / \mathrm{C}$, the seniors. (MIDN $4 / \mathrm{C}$ and up are official Navy ranks, as all the students are in the Navy and enjoy GI Bill benefits if they leave after 2 years, as they may do without punishment.)

If the battle-cry of Modernism, the movement of which most cultural historians agree Woolf was a seminal part, was the injunction of Ezra Pound to "make it new," much of what goes on at Annapolis, by contrast, is justified by "tradition," the belief that things were ever thus and should ever be a certain way. There have of course been changes in the twentieth century and beyond. Of these, the introduction of women in 1976, and the more recent push to get and keep at any price midshipmen of color, many with radically lower predictors than applicants rejected to guarantee their admission, have had the greatest influence on physical standards and the honor system. There is no ongoing physical training, and midshipmen have to pass a Physical Readiness Test only once a semester. Plebes may no longer be touched or "dropped" for pushups by their trainers, and runs are strictly limited in length. Midshipmen nowadays get one "free" honor offense, as students put it to me, that is "remediated" rather than resulting in expulsion as it would have in the old days. The thinking seems to be that the Dean of Admissions has worked hard to recruit them, so we're not going to throw them out now: our goal is to get officers of color, or women.

Yet the administration, with its emphasis on tradition, denies that the alterations have in fact represented real changes even though it seems clear they have. If they wait long enough, which is to say a decade or two, no one will remember when these changes were instituted and the illusion will prevail that they date from the beginning of time. For example, the yearly ritual for plebes of climbing a greased obelisk to remove a cap that's been put there as a rite of passage at the end of their year (in its current form this practice dates from the 1950s), are absorbed into the institution as part of "tradition" that now cannot be altered (in 2010 the grease was removed, to great outcry) or abolished (an increasing threat to this ritual, justified in the view of many observers, where students climb on each other three and four deep and many get feet in their eyes and mouths, not to mention private parts).

The service academies are based, even more than the military itself, on the premise that control is good, and that future officers need to be told what to do every minute of every day; the administration in control before the current one, that lasted 2007-2010 before the Superintendent (a 
Vice-Admiral) was removed a year as a result of irregularities in expenditure of funds for minority outreach and athletic recruiting, came in proud of what it openly (and to civilian Ph.D.s divertingly) called its "intrusive leadership." For most people of the modern age, indeed, things that are intrusive are bad. At Annapolis, they are good. Similarly, past Superintendents have focused on eradicating "individuality" at the Naval Academy as one of the prime sources of problems: in the modern world, this is typically the highest goal. (We Ph.D. moderns also find it diverting that "indoctrination" is used at Annapolis in a completely positive and non-ironic sense: you want to be indoctrinated into correct doctrine, which is to say what authorities are telling you.) But whoever the Superintendent happens to be, the Naval Academy has an opinion about every aspect of midshipmen's lives: where they live, what they wear, when they eat, when they study, when they leave, where they live, and whom they may have a relationship with and what kind it has to be, just to start with a few of the basics. Many courses are mandatory; the administration pushes students toward technical majors to respond to "the needs of the Navy." One anguished about-to-graduate senior, too much in sync with the spirit of the twenty-first century, asked me: "When are they going to trust me to make some decisions? The day I graduate?"

A particularly winning compendium of Victoriana and Victorian morays is found in Judith Flanders's Inside the Victorian Home, which goes through the Victorian houseprison and workhouse of women, in Flanders' view-room by room and quotes lavishly from books, letters, novels, and advertisements to pile on Flanders' indictment against the infuriating smugness of the Victorian patriarchy. Flanders notes that, for our Victorian ancestors, doing what you were told and being obedient to the higher authority was its own end. She offers as an example from Samuel Butler's semi-autobiographical novel The Way of All Flesh, which portrays a father named Mr. Pontifex. As Flanders sums up the view of the Victorians (and of the service academies): "Moral law was to many synonymous with religious law. . . . Any disobedience subverted this notion of order. Therefore disobedience was, of itself, subversive, and it was the idea of rebellion that needed to be punished, not whatever the act of disobedience itself was" (70-71). The common thread between the Mr. Pontifex and the military academies is the apparent belief that having subordinates who ask questions, or even think of asking questions, shows you're not doing your job of keeping them in line. Underlings are to carry out the wishes of the leader merely because he insists they do so. (After all, in 2009 the USNA administration denied me [a tenured full professor] a voted pay raise and slapped me with an official reprimand for questioning its admissions policies in a newspaper editorial; the Office of Special Counsel had to intervene, finding that the administration had retaliated against me for exercising Constitutionally protected rights. Each member of the military swears an oath to defend that Constitution.)

Controlling midshipmen - the rules, and their interactions with the rules - defines the Naval Academy's nature and takes up much of the institution's energy, as if one Mr. Pontifex were replaced by the next at the helm of the institution. It's the ultimate patriarchal society, where Father (the system and the Superintendent) by definition always know best. Most control is exercised over first-year students, known as plebes. Practically every aspect of plebe life is regulated. Plebes must "square corners" in the single large dormitory, Bancroft Hall—which means they make $90^{\circ}$ angles as they turn a corner - at which point they must yell something "motivational," like "Go NAVY!" or "Beat ARMY!"; they are not allowed to nap; they must answer questions from the upperclass at meals; they have "comearounds," which involve screaming the officers of the day and dining hall menus at the top of their lungs; they must "plebe their covers," which means carry their hats with their fingers extended inside the brim - and so on. The precise rituals change (plebes need no longer "eat a square meal," which means moving the fork at right angles to their face, though they must still sit on the front 6" of the chair) but the fact of control does not. The control diminishes over the four-year curriculum as students rise in rank, but it never goes away, and the reins can be yanked at any moment at the whim of a sitting administration or the arrival of a new one.

All this control is defended by the academies' staunchest advocates as necessary for the production of officers- to the extent it is defended at all, rather than being taken for granted. The academies are the cracks where the Victorian world has lodged, continuing to believe as they do that what they do is desirable, even necessary. Yet the world has long ago proved, simply by providing alternative commissioning tracks that are apparently just as effective, that this way isn't necessary. And the strain of the institutions trying to keep up the pretense that it is causes most students, in my experience, to become embittered and listless. Apparently this way of proceeding isn't even desirable, at least not in the modern world where the old-fashioned ways of doing things will seem not normal, but abnormal.

For while the academies apparently weren't paying attention, the world in which the academies operated went and changed around them. It's no longer 1917, after all, when all but a few Naval officers came from Annapolis (these few largely from promotion through the ranks). For officer production, ROTC programs are the modern alternative. These have existed in their earliest state at Land-Grant universities since the last years of the Civil War. (Summarized from Arthur T. Coumbe and Lee S. 
Harford, U.S. Army Cadet Command-The 10 Year History (Fort Monroe, VA: Office of the Command Historian, U.S. Army Cadet Command, 1996), excerpted on http://academic.udayton.edu/rotc/hist-rotc.htm) Initially, however, they served primarily as feeder sources for the reserve corps, and produced a minimal number of regular officers compared with the Academies, until the Selective Service Act of 1948, which promoted the production of regular officers in university setting; the ROTC Vitalization Act of 1964 increased the numbers of ROTC-trained officers yet more.

By the twenty-first century, in each armed service, the associated service academy was producing less than $20 \%$ of that service's officers. As the Pentagon's Web site on source of commissions notes, for FY 2002 (the latest data available) "the largest proportion of FY 2002 officer accessions (33\%) came through ROTC programs . . . Direct appointments and academy graduates accounted for $11 \%$ and $15 \%$ of incoming officers, respectively. OCS/OTS produced about $29 \%$ of FY 2002 Active Component officer accessions" (Population Representation in the Military Services, chap.4, https://www.defenselink.mil/prhome/ poprep2001/chapter4/capter4_3.html).

The small fraction of the officer corps produced by the academies is extremely expensive to taxpayers. The study of "Comparative Analysis of ROTC, OCS and Service Academies as Commissioning Sources" put out by the Advanced Management Program of the Navy Supply Corps School's Advanced Management Program (Tench Francis School of Business) concludes: "DoD invests approximately four times as much to produce a single academy graduate as it invests to produce a single ROTC graduate. Academy graduates cost approximately eight times as much as Officer Candidate School (OCS) graduates" ("Comparative Analysis of ROTC, OCS, and Service Academies as Commissioning Sources," Advanced Management Program, Tench Francis School of Business, Navy Supply Corps School, November 19, 2004).

Sometimes we hear that academy products pay for their so much more expensive commissioning track by staying in longer or progressing faster. As for progression, the same study notes that "no significant difference in officers' progression through the lower ranks, based on commissioning sources, has been observed." And its overall conclusion is that "commissioning source quality indicators of success (retention, career progression and attainment of flag rank) reveal commissioning sources are essentially indistinguishable during officer's careers."

To be sure, academy graduates enjoy minimally greater retention at the 15 year mark: the study observes that "retention of service academy graduates (at 15 years) is on average about six percent higher than officers commissioned through ROTC or OCS/OTS." (The OCS figures are higher than the NROTC ones, upper thirtieth percentile vs. mid-thirtieth percentile, and hence closer to the Academy figure of forty-one percent.) And the one apparently clear advantage of academy graduates over officers who come through other commissioning sources is in their much higher representation at flag officer ranks: to stick with the Navy, the percentage of Admirals and Vice Admirals who have been Academy graduates is $65 \%$, with only $16 \%$ and $19 \%$ provided by OCS and NROTC, respectively. Thus, as the study puts it, "service academy graduates have historically experienced the greatest success in attaining senior officer ranks."

Yet "the advantage in achieving the general/flag officer ranks has diminished over the last two decades" across all services: in 1972, the percentage of service academytrained general/flag rank officers was forty-two percent, against only five percent for ROTC and OCS. By 1990 these proportions were thirty-three percent academy, fortyone percent ROTC, and fifteen percent OCS. And the study notes that we should be leery ascribing this fact to greater quality of USNA graduates: "it is not clear whether this tendency [for Academy graduates to make up a significantly higher percentage of Vice Admirals and Admirals] is due to the quality of service academy programs or other factors that have tended to favor academy graduates" (5-6).

It's clear we should resist assuming that this is causal: it's not necessarily true that if you go to the Naval Academy, you'll have a better chance of making flag officer, though this is how the fact is spun to midshipmen. ROTC now provides a much higher proportion of officers than it did in the late 1960s and 1970s, and USNA a much smaller one. This will of necessity change the pool of flagofficer-wannabes, and weaken the "old-boy network." Furthermore, we promote the people we promote. Saying that flag officers have been largely Academy graduates is like saying they've been overwhelmingly white men: we needn't assume this pattern will continue. We currently see the decision being implemented to promote officers who will ensure "diversity" and female representation. Primacy for USNA graduates need not continue either, especially if there are more officers from other sources to choose from. Nor should we conclude that the (say) NROTC officer won't stay in long as long as others, and so won't be there to be considered. Perhaps the decision to retire was made because of a lack of promotion. The promotion itself ensures desire to stay in many cases. If the Naval Academy ceased to exist, after a time all admirals would by definition come from other feeder sources: the causality may well be the individuals, not the institution that houses them for 4 years. It's sometimes said that academy graduates are more conversant with the toys than ROTC graduates, an advantage that apparently evaporates within a few weeks, 
or months at most: is this worth the multiplied taxpayer cost? Few people would argue that it is.

Woolf's narrator uses the word "generalizations" and then meditates that

The military sound of the word is enough. It recalls leading articles, cabinet ministers - a whole class of things indeed which as a child one thought the thing itself, the standard thing, the real thing, from which one could not depart save at the risk of nameless damnation. Generalizations bring back somehow Sunday in London, Sunday afternoon walks, Sunday luncheons, and also ways of speaking of the dead, clothes, and habits - like the habit of sitting all together in one room until a certain hour, although nobody liked it. . . . How shocking, and yet how wonderful it was to discover that these real things, Sunday luncheons, Sunday walks, country houses, and tablecloths were not entirely real, were indeed half phantoms, and the damnation which visited the disbeliever in them was only a sense of illegitimate freedom (47).

At Annapolis and its sister academies, there are a great many habits that no one likes yet are held to be real, and which have not been thrown in the dustbin. A comparison with ROTC would suggest that all these so-real things at Annapolis and its sister academies really aren't - are already half-phantoms, only those inside the walls either don't know it or won't admit it. For in ROTC or OCS, much of the substance of life at the academies - as Woolf suggests of what seemed unalterable and "real" about the Victorian life- has simply been thrown in the dustbin. An NROTC cadet at, say, Vanderbilt, puts on a uniform a day or two a week and takes a few military classes. S/he squares no corners, can go out when s/he wants, decides when to study and what to major in, and, if of legal drinking age, whether and how much to drink, and whom to spend the night with. Then $\mathrm{s} / \mathrm{he}$ is commissioned, and serves alongside the Annapolis graduates who marched tours in the rain because they failed to be back in time for a muster, got busted for sex in the Hall and almost failed to graduate, or who had to take courses they knew they'd never use. The punch line is this: no one says that Academy graduates are any better in the long run than ROTC products. Over and over I hear, when I ask officers in the Navy what the best all-around commissioning source is: "it depends on the individual." ("Better" is subjective, so anecdotal evidence is all there is.) Indeed, rather than Academy graduates being clearly better, such anecdotal evidence suggests that many new graduates assume an air of superiority which doesn't go over well with the enlisted people, the so-called "ringknocker" mentality (after the huge college rings our graduates sport).
There are other concepts too that are given pride of place at the service academies, those theatrical exercises where the military puts itself on show for the world. These are notions conceived of as substantial entities, that are possessed or taught or define one's being. "Honor," a notion dear to the Victorians, has disappeared practically everywhere but in the military (the Marine Corps Hymn says the function of Marines is to "fight our country's battles and to keep our honor clean")-and is particularly foregrounded at the service academies. Students can be found "in violation of the Honor Concept" which states flatly that "midshipmen do not lie, cheat, or steal"; in theory this is supposed to lead to expulsion (called "separation") but nowadays rarely does. Indeed the extreme nature of student disillusionment about the institution comes largely, I believe, from the fact that the academies promise real dedication to things like honor, that apparently can be lost with a single lie, and do not live up to that talk. The idea behind the separation is apparently that someone without honor, as a liar will show him- or herself to have been, is unfit company for those who possess it: at least this is the sentiment I hear repeatedly from midshipmen, outraged that students found in violation are retained and "remediated" (undergo lectures about honor) rather than being separated.

"Gentleman" too is a quaintly old-fashioned, albeit attractive concept that is part of Naval Academy parlance: a midshipman passing two or more male officers or an officer and a professor greets them with the plural of "Sir," which is "Gentlemen." It's not coincidence that "gentleman" is linked for most people with the word "officer," as in "an officer and a gentleman"- when it's not preceded by the word "last." Otherwise in the world outside, people think it has something to do with holding doors for women, and so has fallen into disrepute as a result of the feminist 1960s. "Character" is something the academies focus on as well: we offer what we unironically call "Characterdevelopment seminars," as if character were a muscle group that could be hypertrophized in the gym.

All of these are pre-Industrial concepts that suggest that people are defined by what they are rather than what they do. A "gentleman" means someone who doesn't work, and in the Victorian era, when these concepts arguably hardened and became defensive as fortunes were suddenly made in "trade" or manufacturing rather than being inherited in the form of land, honor and character were things that working people didn't aspire to.

Of these concepts, "leadership" seems to have lodged most comfortably in the officer corps of the military and to be paraded most theatrically at the service academies: after all, if they don't teach "leadership" (not to mention "character" to "gentlemen" [and ladies] of "honor") why should the taxpayers continue to support them in a world 
where ROTC has the lead? The academies all claim that apparently unlike ROTC or civilian colleges today, they teach "leadership." This is another term that has also largely, in the modern world, been thrown in the dustbin, victim to the result of increasing specialization and the trend toward demanding that people in the workplace actually possess skills, not merely show leadership. Outside of the military academies, tellingly, it also enjoys great reverence in business schools, where the precise nature of the skills taught is nowhere near as clear as, say, in a medical school, or a graduate school where there is little talk of "leadership" and much talk of the subject matter.

Leadership, like "gentleman," "honor," and "character," is a substantialized but mystical notion for something either one has or is (or not)-similar to the way "purity" (virginity) was held by the Victorians to be a real commodity that could be sullied or lost. Such substantialized conceptions emanate from a society governed by tradition and control, like the Victorian age or their modernday avatars, the military academies. They are supposed to ensure predictability, but of course they don't: a substantialized notion of "character" doesn't stop you from doing something out of character, or losing your honor, of failing to show leadership. Or sullying your purity, for that matter.

Claims to creating leaders figure prominently in the mission of the academies. The long-winded mission of the Naval Academy is "to develop midshipmen morally, mentally and physically and to imbue them with the highest ideals of duty, honor and loyalty in order to graduate leaders who are dedicated to a career of naval service and have potential for future development in mind and character to assume the highest responsibilities of command, citizenship and government." West Point is even grander on its Web site in its claims to teaching leaders: "Renowned as the world's premier leader development institution, West Point accomplishes its mission by developing cadets intellectually, physically, militarily, ethically, spiritually, and socially."

Insisting on using a map where a large spot is called "leadership," as the military and the service academies do, is like insisting on a map of Europe that includes the Austro-Hungarian Empire. It's not that this land mass has disappeared, it's just that it's been broken up into constituent parts in the modern world. Comparable constituent parts of "leadership" are smarts, diplomacy, ease with people, commitment, and willingness to listen to others. Some of these parts can be developed (smarts), some can be modeled (willingness to listen), but others you have or don't have. Once you subtract all these things, there's nothing left for "leadership." The problem is that there's no evidence either that "leadership" can be taught, or that the academies teach it better than comparable cheaper and more modern institutions. Yet students at Annapolis and at West Point take mandatory classes in "Leadership," for which they receive academic credit. And there's no evidence (see above)) that they are better than officers from other institutions who didn't.

Still, it's clear why the military gives pride of place to this old-fashioned vocabulary, and the pretense that we can teach "leadership" at its academies. Given that it's the enlisted people who have the skills in the military-they're the ones who actually work the machines - what's left for the officers? How else, other than by holding on to the idea that the service academies teach "leadership" in addition to physics and English as civilian colleges do, can we justify civilians paying for the academies?

But insisting on the existence of a substantivized notion of "leadership" isn't just academic waste; doing so also seems to have a negative effect in the real world. In the military as at the academies, the concept is, in practice, used to justify decisions based only on the command officer's gut instincts: he's exercising "leadership" based on "character." If all his (or her) decisions are based on his/her "character" then questioning these decisions question his or her most essential being, not to mention the precious commodity of his or her "leadership." It takes a special kind of person not to equate criticism of the way things are with criticism of the person who made them that way. A command, after all, is Colonel So-and-so's until he is "relieved of command." So military underlings with views the brass don't want to hear almost always get squelched, and are branded malcontents. The result is that problems multiply and fester until they erupt, rather than being addressed early on.

This is one of what, in my book Bridging the MilitaryCivilian Divide, I call the military's "structural weaknesses," which we need to actively minimize, though they cannot be completely eliminated. The alternative is to minimize the notion of personal "leadership" that draws on "character" and "honor" (which disagreement apparently questions or denigrates), and maximize the idea that decisions are made based on evidence, that all can help provide and aid in evaluating. We could point out that a decision doesn't eminate from a magic black box called "leadership" or "character," but results rather from reasoning: thus we could, if we minimized "leadership" and maximized reasoning, get help in justifying the best possible course of action among alternatives, and in saying why. This after all is largely the way the civilian world outside functions, a world that has moved beyond the Victorian age.

Even if, as seems unlikely, leaders can be mass-produced at the academies, who says that what the academies do is the way to do it? Perhaps what we do is very good at producing worker bees and very ineffective at producing leaders. Yet the only justification offered for the effectiveness of academy education is the same list of a dozen great heroes who came from whichever academy: we don't ask if 
these people might have been the same whatever their commissioning source, or whether the same number of heroes come from other commissioning sources, or what to make of the countless thousands of lesser products we also produce. If you're stuck in the year of Queen Victoria's Jubilee, or listening to Carlye's lectures on heroes from the year of her accession, modernity doesn't exist and you don't have to justify yourself with respect to it. You just do what you do.

Yet we make the pretense of having chosen what we do among alternatives. Several of our superintendents in recent decades have spoken of Annapolis as a "leadership laboratory." The scientific terminology is revealing, in that it's inappropriately used. In science, from which the word "laboratory" is borrowed, you can't merely assert that rats fed on, say, broccoli, are going to be healthier rats. You have to define "healthier" and you have to run a controlled experiment to find out if they are or not. You feed half the rats lots of broccoli and the other half less, or none: even so you have to consider the possibility that the other things you do feed the low-broccoli rats will determine your results.

Yet the service academies don't try out competing paradigms for producing leaders, only one. We assert loudly that we produce "leaders" but no attempt is made to substantiate this assertion, or to substantiate the assumption that what we do is the best way to do it, if it can be done at all. Of course we produce officers, because we make them such the day they graduate. But leaders? That's a different story-unless we're declaring the two to be identical, in which case we can graduate anything at all and declare success. Which is basically what we do. Leadership, in fact, is the natural enemy of scientific justification: it's mysterious, and produced by the individual. In science, nothing is mysterious, and if the results of an experiment, if valid, are reproducible by anybody.

Most of the "leadership" opportunities the academies offer take the form of giving a few of these so-controlled people a large margin of personal control over those lower than they in the system: more senior students run "plebe summer" for the newly arrived ones, for example. For many of them it's the first time they've ever had people do something just because they said to do it. Yet there's no proof these young and usually inept controllers actually get better as a result of this exercise, or that they would have been any worse leader in the fleet without the experience. Of course they experience something new, but who's to say they aren't good or bad leaders later on simply as a result of basic human intuition and decency, or their lack-that is, that they get it right or wrong the first time? Besides, bad leaders with close to absolute control over younger students can have extremely negative effects on those in their power. It may well be that this outweighs (perhaps by a good margin) the positive experience of the (few?) good ones. We don't know, because nothing we do is scientific, nothing is justified. It's as if we were still the Church of England ignoring the scientific hypotheses of Mr. Darwin. Mostly the Naval Academy lacks these face-to-face human situations anyway: the bulk of what midshipmen do involves no such "leadership" opportunities, but, as the students tell me with exasperation, are merely exercises in rubber-stamping what the administration decides.

The belief that the best way to offer "leadership opportunities" is by giving older students power over the younger was, of course, a staple of the Victorian public school system as instituted by Mr. Arnold of Rugby, so devastatingly skewered by Lytton Strachey in Eminent Victorians. The fact that in this system, someone scarcely older than you had the power to tell you what to do, and usually exercised this power malevolently, figures prominently in many memoirs of school of the time, usually not positively. George Orwell's excoriating critique of his public school in "Such, Such Were the Joys" is one of the more widely read of such bitter recollections.

Strachey's skewering of Arnold's pecking order of power would be timely if aimed at the American military academies today. Strachey quotes the father in the popular novel Tom Brown's School Days who "doesn't care a straw for Greek Particles, or the digamma" and wants only that his boy, whom he is sending to Rugby, "turn out a brave, helpful, truth-telling Englishman, and a Christian." (Presumably the father wants the son to have a good "character.") Strachey then imagines Arnold accepting this charge (putting thoughts in his historical characters' mouths, a writing tic for which he was much criticized) and meditating on how to proceed. "[H] ow was he to achieve his end? Was he to improve the character of his pupils by gradually spreading around them an atmosphere of cultivation and intelligence? . . By introducing into the life of his school all that he could of the humane, enlightened, and progressive elements in the life of the community? On the whole, he thought not" [118]. Then how? According to Strachey, Arnold concluded that he "would found a theocracy."

Annapolis arguably worships these days at the church of football: in the Victorian age, and the first half of the twentieth century, chapel attendance was mandatory. Now attendance at football games is mandatory and the student body marches the mile to the stadium through the streets of Annapolis while locals throw candy. Every "motivational" yell of "Beat Army" refers to a football game, and the biggest public celebrations involve the painting up for football games of the totemic figurehead in front of the dormitory building. A victory by the football team over Army produces liberty for the whole Brigade. Yet the result is the same as a theocracy of religion. 
Strachey goes on to outline the hierarchical system of the Victorian public schools, a system that is still firmly in place at Annapolis, where the plebes are under the control of juniors, with seniors at the top of a chain of command and with specific seniors in charge of their peers as company student-officers, companies being the groups of about 100 students into which the student body, the Brigade of Midshipmen, is divided.

For this purpose [founding a theocracy], the system, prevalent in most of the public schools of the day, by which the elder boys were deputed to keep order in the class-rooms, lay ready to Dr. Arnold's hand. He found the Praeposter a mere disciplinary convenience, and he converted him into an organ of government. Every boy in the Sixth Form became ipso facto a Preaposter, with powers extending over every department of school life; and the Sixth Form as a body was erected into an authority responsible to the headmaster, and to the headmaster alone, for the internal management of the school (119).

Lindsay Anderson's film "If ..." set in a fictional 60s-era but still late-Victorian throwback school (complete with black and white sequences to suggest timelessness) focuses on this aspect of life under the thumb of the newly empowered and incompetent senior students, to justify the subsequent rebellion by the others, who take the school's military-practice guns and shoot the headmaster. The viewer roots for the rebels.

Yet another similarity between the Victorian world-view and the military academies is that for both, suffering was a good thing - after all, it built character. Much of the modern world takes the more pragmatic view that suffering is to be reduced or avoided as it gets in the way of accomplishing the mission. For the Victorians, it seems to have been the mission. As Flanders puts it, of the Victorians: "A mother's or nurse's refusal to feed her infant except at stated hours taught the infant the benefits of "order and punctuality" (71). Apparently, suffering had moral worth for the Victorians. Though chloroform, an anesthetic, was available to help women get through childbirth, Flanders notes that it was resisted by many on the grounds that it seemed to contravene Genesis 3:16, which condemned the daughters of Eve to bringing forth children "in sorrow" (54). Annapolis students are largely sleep-deprived and frustrated, miserable and distracted. Yet no measures are taken to let them nap or reduce their frustration: repeatedly they are told to "suck it up," tolerate any degree of bad things.

We now know that in medicine, more intervention frequently isn't more cure: sometimes the treatment is worse than the problem. But at the military academies, where no actual mission limits our assertive head of steam, we can assert that "intrusive leadership" is necessary to keeping officer candidates on the strait and narrow: liberty is circumscribed, the permissible times for wearing civilian clothes are reduced. The remedy is like much Victorian medicine: it seems clear that in fact it makes things far worse. At least that was my conclusion from seeing that it took my seniors a quarter of an hour to calm down from their fury at the beginning of classes in 2007, when the liberty they thought they'd earned through seniority was curtailed and the hours in which they could wear civilian clothes were all but eliminated. Though they had spent 3 years earning back these privileges only to see a new administration wipe them away in an instant, their fury was dismissed by the Superintendent noting that the U.S. was "at war." Suck it up. The boys in the field do. Suffering apparently builds character, at the academies as for the Victorian child.

The lack of any justification for what was insisted upon so forcefully didn't stop the Victorians from asserting it. No more does it at the service academies. Since Victorian women and children weren't to talk back, and medicine was by later standards primitive, the area of health of women and children was fertile field for forceful pronouncements backed up by nothing but "leadership," as the military now calls it when it applies the same attitude to healthy young adults. The Victorian response to problems during teething time, for example, "was to give purgatives ...., put the child in a hot bath, and if necessary lance the gums." Flanders comments: "Children who had once had trouble ... with their teething ... would shortly have problems caused by the purgatives and opium that had been administered to treat them" (80). Still, this is what the doctor would have ordered, and been firm about it too. To a world that merely asserted, exerting leadership, it made sense-especially if asserted loudly and firmly and by a figure of authority.

Like the Naval Academy, the Victorian home was a world of endless make-work, a constant round of chores whose purpose was, to large degree, apparently just themselves. As Flanders puts it, "the link between morality and housekeeping was made time after time" (115). Cleanliness was re-defined, it seems, to be that which could only be attained by constant intervention: work expanded to fill the time devoted to its completion. So too the endless round of room inspections, uniform inspections, racks (beds) torn up because they have a wrinkle, rooms having to be cleaned from the top down all over again because there was a spot of dust. (In ROTC programs, none of this happens, and yet the product is apparently just as good.)

In the Victorian world, Flanders points out, utility was routinely sacrificed to custom or habit. (At the Naval Academy, we invoke tradition.) In Flanders' example, the British insisted on keeping the open fireplaces they were 
used to, though they were far less efficient than the alternatives such as German-style closed tile ovens (108109). These alternatives were rejected, or never seriously considered, on the specious grounds that they used up the air in the room - and no one drew any conclusions from the fact that the Germans weren't dying from asphyxiation as a result of their own tile ovens. We insist that the Annapolis way of making officers is the best way, indeed perhaps the only insert-adjective-here ("real"? "correct"?) way. But actually, we have proof this isn't so: other commissioning sources produces officers that are just as good. Still we draw no conclusions, or deny the ones staring us in the face.

The Victorians insisted that masturbation in pubescent boys led to warts, blindness, and even imbecility-all without a shred of justification. Doctors asserted this vehemently; indeed all evidence suggests they believed it. To us, it seems the reasoning was backwards: they objected to masturbation as they apparently did to all sexuality not directly related to the production of children, but couldn't say this. So they made a claim whose justification mimicked a scientific reason without being one. Nowadays, forbidding masturbation has lodged where it belongs, in the crevasses of religion. And, well into the modern age, in Annapolis.

Alfred Kinsey's ground-breaking Sexual Behavior in the Human Male noted that "The United States Naval Academy at Annapolis considers evidence of masturbation [what would this have been?] to be sufficient grounds for refusing admission to a candidate (U.S. Naval Acad. Regl., June 1940)" (264). I imagine this "Regl." is now outdated: we did not consider the issue the issue of masturbation during my time on the Admissions Board. However, some of the same attitudes that produced this regulation are alive and well. In 2011, hoping in my office to check this page of Kinsey in the search option of the www.Amazon.com listing for this now-classic and much-reissued work, I clicked on the title as it appeared on Amazon.com. I found myself looking at a page, to which I had been automatically re-directed, that read: "United States Naval Academy: Honor, Courage, Commitment" and then: "You have been directed to this page because the web page you were trying to access is restricted by the USNA Acceptable Use Policy and/or Department of the Navy Internet usage policies. Reason: The Category 'Sex' is filtered."

Most telling of all, any sex is forbidden within the confines of our 300 plus acre Yard. Students can be separated for "sex in the hall" (or its correlative, "conduct unbecoming an officer" that is used here against midshipmen as well); PDA, public displays of affection, are forbidden, and a kiss can cause students to march tours toting a rile. The fact that this makes sex Hobbesian-nasty, brutish, and short-and drives it underground or off campus seems an echo of the way Victorian prudishness produced the great effleurescence of what to us is strange erotica of the Victorian underworld: nice girls didn't, so what did that leave?

The attitude of the service academies toward clothing is Victorian as well. Clothes at Annapolis are keyed to occasions with little room for deviation, in a way they haven't been for civilians since the Great Cultural Divide of 1968 , into which fell the concept that specific occasions required particular clothes. It's not just that people dress down these days, as seen in, for example, the fact that running shoes and T-shirts are ubiquitous, and men eat dinner in expensive restaurants with baseball caps wedged firmly on their heads, or wear t-shirts to the opera. More fundamentally, the idea that specific functions that require specific clothing is gone as well. If a garment keeps you warm enough and is decent (and frequently when it isn't), it's good to go. Not so at the academies, which take all the military's uniforms and add some, and so foreground as an end in itself all the changes necessary as a result that plebes are drilled on the speed with which they change from one outfit to another.

Academy dress ranges from mess dress, with gold cummerbund, at the top end, through the gleaming choker whites of our graduation day, through the double-breasted black suits that the Navy insists are blue (SDBs, Service Dress Blues), to open-necked kahki, and down to camouflage and gym gear. Every midshipman is a Ken (or Barbie?) doll with a full wardrobe. And you can't make up when to wear what. It's as rigid as "dressing for dinner" for the Victorians, which meant a white tie and tails, and when "street clothes" meant merely a suit-and when tweeds were only for the country.

I've been proposing that the service academies echo and try to keep alive many of the Victorian mores that have died in the world outside. The problem is that when a vanished world is kept alive artificially, it seems artificial to those who come to it from outside. And so the academies seem increasingly to their students.

It's true that the world holds extreme situations: they're extreme because they're not representative, fall outside the ordinary. Combat is one of them. A state of readiness for combat is, though somewhat diluted in intensity, is another. It is of course true that in combat, there is not time for discussion, or rational exchange of views. Everyone must line up behind someone whose authority to have action happen is unquestioned. This is true even if, as occasionally (or perhaps even more often than occasionally) this authority makes the wrong decision and sends people hurtling over a precipice - or into the "valley of death," as in the case of "The Charge of the Light Brigade." Still, the men charge on. Organized action, even if sometimes quite wrong, is (we hear) preferable to lack of any organization whatsoever. 
But does that mean that we can apply these rules meant for exceptional circumstances to situations that are no longer exceptions? Can we live everyday life at this fever pitch, in a kind of self-motivating pretend situation? To True Believers, such as the Victorians or defenders of the military academies as they are today, we not only can but should. What's right for battle readiness is right for " 4 years by the Bay," to quote "Navy Blue and Gold," the school song. I can't argue with the "should": that's a matter of faith, nothing more. But when we examine whether or not this can be done, we quickly come to the conclusion that it can't - except at the price we in fact pay daily, weekly, yearly, at Annapolis, for trying to keep alive the vanished world of the Victorians in a situation where every vestige of functionality has been removed.

We're not at war-not at the academies. Nobody dies (except the occasional student with a heart problem). Yet the students are repeatedly told that "people die if you X," where $\mathrm{X}$ can be anything from leaving lint on their uniforms to failing to make their beds. They realize it's much ado about nothing. There may be extreme situations where extreme rhetoric is justified, where suffering must be borne, and where attention to miniscule details must be minutely paid at the price of, in fact, people dying. But the academies are not such places. They play-act at being such places, and end up seeming only ridiculous to their students.

That price is student disillusionment and a destruction of drive. It's not possible to keep alive a viable Victorian microcosm in a world so resolutely modern. It's the impossibility of East Berlin when the East Berliners could see the buildings of West Berlin and watch its television. The pretense of greater morality, of sacrifice, and of suffering building character (as East Berliners were told the Westerners were decadent because they had so much) rings hollow. Midshipmen can see that officers produced by much less "intrusive" means are no worse. They talk to friends who are not policed the way they are policed, and make the comparison: it's not clear that they themselves, with all their rules, turn out any better. The academies today, trying to be Victorian, end up as military Disneylands - to the disgust and agony of many of their students, who came thinking that after all it was possible to turn back the clock.

I know this is what the students think because I talk to them. And I read their papers. Several years ago, searching for a freshman paper topic related to Keats's "Ode on a
Grecian Urn," I asked them to compare their views of the Academy before arriving to what they found when they got there. (The idea was to comment on Keats's assertion that "heard melodies are sweet, but those unheard are sweeter.") Almost all the students in two classes, about 40 in total (freshman classes, which even full professors teach, are small), wrote agonizingly of dreams that had been dashed by reality. What they imagined was honor, loyalty, and motivation. What they found was the hypocrisy that Strachey and the Modernists saw in the Victorians, and the lies necessary to prop up the fiction that life could actually be better than it is.

Urn life, Keats's narrator makes clear to us, is our inaccessible ideal: we can sculpt it or speak of it, but never live it. The disillusionment of those told that father really did know best, on finding it wasn't so, was extreme: Strachey and Woolf are only two of those who felt liberated on having things a whole world had asserted to be real show themselves to be half-phantoms, or whole ones.

Midshipmen at the service academies are making a valiant effort to live a lie; few are succeeding in convincing themselves they are succeeding. If the Victorian age, Woolf thought, was dead in 1917, what is it now? Perhaps it is a version of Marx's notion that history comes first as tragedyas the Victorian world died in the tragedy of the first World War-and then as farce, the fancy-dress Potemkin villages of the service academies that delight tourists drawn to their pomp and disappoint most of their cast members so utterly.

\section{Further Reading}

Flanders, J. 2005. Inside the Victorian home: A portrait of domestic life in Victorian England. New York: Norton.

Kinsey, A. 1948. Sexual Behavior in the Human Male, Philadelphia: W.B. Saunders; Bloomington IN: Indiana University Press.

Strachey, Lytton. 1990 [1918]. Eminent Victorians: The Biographies of Cardinal Manning, General Gordon, Florence Nightingale, and Thomas Arnold. New York: Penguin Classics.

Orwell, G. 1953. Such, Such Were the Joys. New York: Harcourt, Brace.

Bruce Fleming has taught English at the US Naval Academy since 1987. His most recent book is "Bridging the Military-Civilian Divide." He has recently published op-eds in the New York Times and the Washington Post, and essays in the Antioch, Yale, and Southwest Reviews, among other venues. His Web site is www.brucefleming.net. 